\title{
The Marine Life of an Offshore Oil Platform*
}

\author{
A. Wolfson ${ }^{1}$, G. Van Blaricom ${ }^{2}$, N. Davis ${ }^{3}$ and G. S. Lewbel ${ }^{4}$ \\ 1 International Biological Consultants, 819 DeWitt Avenue, Encinitas, California 92024, USA \\ 2 U.S. Fish and Wildlife Service, Piedras Blancas Station, San Simeon, California 93452, USA \\ ${ }^{3}$ Chambers Consultants and Planners, 10557 Beach Blvd., Santon, California 90680, USA \\ 4 L G L, Ltd., 1122 Silverado Avenue, La Jolla, California 92037, USA
}

\begin{abstract}
Our research at Union Oil Platform EVA, off Huntington Beach, California, USA, was aimed at understanding how man-made offshore structures function as artificial reefs and how they modify the surrounding marine environment. Underwater surveys were conducted to determine: (1) the distribution, standing stock and productivity of attached 'fouling' organisms, (2) the density, size-structure, and biomass of epibenthic populations beneath the platform, and (3) the abundance, species composition and distribution of epifaunal and infaunal benthos as a function of distance away from EVA. The platform substructure is overgrown with dense clumps of sea mussels. An estimated cubic meter of mussels falls from the platform each day, supporting extraordinary densities $\left(29 \mathrm{~m}^{-2}\right)$ of sea stars on the bottom. Sea stars are prevented from climbing up onto the platform by bands of stinging sea anemones on EVA's base. The adjacent sand community is strongly influenced by EVA's presence with densities of some species greatly enhanced and others significantly reduced by proximity to the structure. A trophic model of dominant faunal elements in the oil platform ecosystem indicates high productivity and turn-over rates for the attached community.
\end{abstract}

\section{INTRODUCTION}

Permanent offshore structures for oil and natural gas production are an expanding feature of the coastal marine environments of the world. These installations are a focus of intensive public interest and concern, particularly since the blowout and oil spill at Platform 'A' in the Santa Barbara Channel, California, in 1969. The soaring rates of petroleum consumption by industrialized nations have stimulated exploration and platform construction in remote and physically hostile locations such as the North Sea and Beaufort Sea, while existing production fields in southern California and the Gulf of Mexico are being rapidly expanded.

Most offshore platforms are placed on soft-sediment bottoms, forming artificial reefs which provide attachment sites for marine life and vertical relief attractive to fishes. Algal spores and invertebrate larvae rapidly colonize submerged portions of platform structures, establishing a 'fouling' assemblage which provides food and shelter for associated fishes. Previous studies of oil platform ecology have concentrated on describing these fouling communities and fish populations (Carlisle et al., 1964; George and Thomas, 1975; Mearns and Moore, 1976; Sonnier et al., 1976; Wolfson 1976). The influence of platform presence on the

- A contribution from International Biological Consultants, 819 DeWitt Avenue, Encinitas, California 92024, USA. underlying benthic ecosystem has received relatively little attention. Our interest in extending research in this direction was motivated by the discovery of an extraordinary congregation of sea stars beneath Union Oil's production platform EVA in southern California, USA. A general review of oil effects on marine organisms will appear in Volume $V$ of 'Marine Ecology'.

Our study at Platform EVA (three km offshore of Huntington Beach, California; latitude $33^{\prime \prime} 10^{\prime} \mathrm{N}$, longitude $118^{\circ} 93^{\prime} \mathrm{W}$ ) had two primary goals: (1) to describe and explain distributional patterns in benthic populations on and near the platform, and (2) to illustrate the potential utility of platforms such as EVA for quantitative biological research. We describe here the animal community attached to EVA, the sea stars on the platform, the assemblage of large echinoderms living below the platform, and the epifaunal and infaunal communities of the adjacent soft bottom. Descriptive data are used to estimate the standing stock and productivity of the fouling community and to model trophic relationships between the attached community and the benthic echinoderm aggregation.

\section{MATERIAL AND METHODS}

Platform EVA, constructed in 1964 on a fine sand bottom (depth $18 \mathrm{~m}$ ), is typical of offshore oil platforms in southern California. Production facilities are located 
on several steel decks supported by 12 vertical legs bridged by horizontal, oblique, and vertical cross members. Oil well encasement shafts descend from the western half of the platform into the bottom. The exposed surface area of all submerged legs $(0.84 \mathrm{~m}$ mean diameter), cross braces $(0.32 \mathrm{~m}$ dia.), and well casings (0.51 $\mathrm{m} \mathrm{dia}$.) totalled about $4600 \mathrm{~m}^{2}$ at installation.

All data and samples were collected by the authors during a series of SCUBA dives in December 1975 and June 1976. The volume of fouling bivalves (mostly sea mussels Mytilus spp.) on the support structure was estimated by measuring circumferences of columns and braces. Twenty-five measurements were made at various depths on legs, cross braces, and well encasement shafts. Net volume of sea mussels was computed by subtracting the volume of the support columns at installation from the estimated total volume derived from our circumference measurements.

Sea stars living on EVA were censused in randomly selected areas, including four vertical legs $\left(242 \mathrm{~m}^{2}\right.$ surface area) and 28 horizontal braces $\left(402 \mathrm{~m}^{2}\right)$ at various depths.

Species abundance and size-frequency distributions of epibenthic biota were assessed in band transects located: (1) directly beneath EVA, (2) beginning at the edge of the platform and extending away from EVA, and (3) in a comparison area $300 \mathrm{~m}$ east of the platform. Transect surveys were made by placing a weighted, marked line on the bottom and censusing animals within either $0.25 \mathrm{~m}$ or $0.5 \mathrm{~m}$ of the line. In every case, counts and size measurements were made on each side of the line.

Core samples were collected along a $100 \mathrm{~m}$ transect which began $10 \mathrm{~m}$ east of the edge of the platform, at the point where debris from EVA's fouling community no longer covered the sand bottom. At eight stations along this transect running eastward from the platform, two cores were collected, along with two (ca. $100 \mathrm{ml}$ ) sediment samples for analysis of grain size distribution and organic carbon content. The coring device was a diver-manipulated metal cylinder which sampled to a depth of $12 \mathrm{~cm}$, with a surface area of $0.018 \mathrm{~m}^{2}$. Core contents retained by a $0.5 \mathrm{~mm}$ mesh sieve were fixed in formalin, then stored in .40\% isopropanol. Infauna were separated from debris, identified, and counted under a dissecting microscope. Sediment grain size distributions were determined by passing dried subsamples of sand through a graded series of sieves, then weighing the fraction retained by each sieve. Sediment parameters were determined from these data by graphical techniques (Inman, 1952). To measure organic content, sediment subsamples were treated with $0.1 \mathrm{~N} \mathrm{HCI}$ to remove carbonate, then burned in a Leco induction furnace carbon analyser.
Estimates of echinoderm standing stock were made in the following way. Large random samples of animals were collected from beneath EVA, drained, weighed, and measured to derive size/weight relationships for each species. Using these relationships, size-frequency histograms produced from transect census data were converted to weight-frequency histograms, from which standing stock biomass estimates were computed for the total population of each species under the platform.

Finally, the thickness of the accumulation of mussel shell debris on the sea floor was estimated by comparing readings of diver-held depth gauges on the bottom under EVA with similar readings on adjacent sand bottoms and with charted bathymetry at the EVA site prior to its installation.

\section{RESULTS AND DISCUSSION}

The Fouling Community

From roughly the mean tide level to within a few meters of the sea floor, the submerged support structure and well casings of EVA were thickly fouled by the mussels Mytilus californianus and $M$. edulis, in an approximate ratio of abundance of $1: 4$ (respectively). All size classes, ranging from $0.2 \mathrm{~cm}$ to $25.0 \mathrm{~cm}$ maximum valve length, were represented. The complex matrix of shells and byssal threads formed by the mussel clumps provides an important source of secondary space and shelter for other fouling species on EVA (Wolfson and Parr, 1975). The degree of encrustation of mussel shells by other fouling organisms appeared to increase with depth.

The space dominance by Mytilus spp. ends a few meters above the bottom. The remaining primary space is covered by densely-packed individuals of a small sea anemone Corynactis californica. This band of anemones at the base of the platform legs may be important in maintaining the structure of the musseldominated community above it. Our data (see below) show that densities of Pisaster spp. (asteroids which feed voraciously on mussels) are markedly lower on the platform itself than on the bottom beneath it. The mussel populations on EVA include high densities of size classes which Pisaster spp. are able to consume (Landenberger, 1968; Feder, 1970; Paine, 1976a). We believe that the band of anemones prevents migration of sea stars from the bottom onto the structure. This could explain the unexpectedly low density of sea stars up on the platform, and account for the spatial dominance by Mytilus spp. of subtidal areas from which they might normally be removed by Pisaster spp. predation (Paine, 1966, 1974). Similar patterns of subtidal 
dominance by mussels occur on natural rock substrates which lack the necessary recruitment habitat for predatory sea stars, or are exposed to heavy wave shock or strong tidal currents which restrict sea star foraging (Chan, 1973; Paine, 1976b). The anemone C. californica, plays a comparable role in influencing structure and zonation of pier piling communities near Santa Barbara, California (Landenberger, 1967), and in another bivalve-dominated (Chama pellucida) community at Santa Catalina Island, California (Vance, 1978). The mechanism of Pisasterspp. repulsion by $C$. californica has not been demonstrated, but appears to involve sensitivity of the sea star's tube feet to the stinging nematocysts of the anemone.

Only two species of asteroids were present on the support structure of EVA: Pisaster ochraceus (average density $\left.0.25 \mathrm{~m}^{-2}\right)$, and Pisaster giganteus $\left(0.1 \mathrm{~m}^{-2}\right)$. Their numbers are probably limited by dislodgement during storms and by the anemone barrier to immigration by benthic populations. Some of the sea stars on EVA may have settled onto the platform as larvae, and have grown to large sizes feeding on the essentially unlimited supply of mussels. These two asteroids showed marked vertical stratification on EVA $P$. ochraceus predominated in the upper three to five meters, while $P$. giganteus was more common below, corresponding to the natural situation in rocky areas where $P$. ochraceus is mostly intertidal and $P$. giganteus is almost exclusively subtidal.

The general features of the subtidal fouling community of EVA are comparable to those of other artificial marine habitats, including pier pilings (Landenberger, 1967), jetties (Haderlie, 1968), and other oil platforms (Carlisle et al., 1964; Shinn, 1974; Mearns and Moore, 1976).

\section{Benthic Epifauna}

The substrate beneath and adjacent to EVA has been completely altered by biological 'fallout' from the platform's fouling community. The bottom was covered with mussel shells, barnacle tests, and other biologically derived material. This pile of debris was occupied by extraordinary numbers of sea stars, which were feeding on mussel clumps containing live individuals that had apparently fallen from above. Sea star densities were so high that animals often were literally armin-arm, completely obscuring the underlying substrate. Near freshly-fallen mussel clumps, sea stars were regularly found piled several animals deep.

Extrapolation from transect data (Table 1) indicates that roughly 19,000 asteroids (wet weight 16.8 metric tons) were concentrated in the $24 \mathrm{~m}$ by $27 \mathrm{~m}$ area beneath the platform, along with about 5000 sea cucumbers (Parastichopus parvimensis and Parastichopus californicus) during the initial survey (December 1975). Resurveys of selected transects in June 1976 suggested that the December data were representative of long-term densities of epibenthic animals.

Table 1. Echinoderm density and biomass estimates for benthic populations below Platform EVA. Density estimates for the two most abundant sea stars are based on average density in two $0.5 \times 5.0 \mathrm{~m}$ transects located on the bottom below the eastern and western halves of the platform. Estimated population densities for the other echinoderms are based on counts from a $1.0 \times 27.0 \mathrm{~m}$ transect which covered more of the area below the platform, providing better estimates for less common species

\begin{tabular}{|c|c|c|c|}
\hline Species & $\begin{array}{l}\text { Density } \\
\left(\text { No } \mathrm{m}^{-2}\right)\end{array}$ & $\begin{array}{c}\text { Total } \\
\text { number }\end{array}$ & $\begin{array}{c}\text { Biomass } \\
(\mathrm{kg})\end{array}$ \\
\hline Pisaster brevispinus & 18 & 11,500 & 10,275 \\
\hline Patiria miniata & 9 & 6,000 & 750 \\
\hline Pisaster ochraceus & 1.5 & 1,000 & 4,000 \\
\hline Pisaster giganteus & 0.4 & 250 & 1,500 \\
\hline Pycnopodia helianthoides & 0.3 & 200 & 200 \\
\hline Dermasterias imbricata & 0.03 & 20 & - \\
\hline Total asteriods: & 29 & 18,970 & 16,725 \\
\hline Parastichopus spp: & 8 & 5,000 & 1,075 \\
\hline Total echinoderms: & 37 & 23,970 & 17,800 \\
\hline
\end{tabular}

In our combined research diving experience in coastal habitats of Pacific North America (3000 dives total), we have observed no asteroid aggregation even approaching the density $\left(29 \mathrm{~m}^{-2}\right)$ under platform EVA. Pisaster giganteus is the most common asteroid of the rocky subtidal zone of southern California (Hopkins and Crozier, 1966). We have recorded maximum densities for this species of 0.23 individuals $\mathrm{m}^{-2}$ in La Jolla, but a more typical density is $0.01 \mathrm{~m}^{-2}$ beneath kelp beds (Rosenthal et al., 1974). The density of $P$. giganteus under EVA $\left(0.4 \mathrm{~m}^{-2}\right)$ represents a two to forty-fold increase over reported natural abundances. The aggregation of $P$. brevispinus is particularly dramatic. The highest density of $P$. brevispinus we had previously recorded occurred on an artificial reef at 14 $m$ depth off Torrey Pines State Park, California, where heavy recruitment of this species apparently occurred in July 1975. Densities on this reef $\left(0.68 \mathrm{~m}^{-2}\right)$ were 30 times less than those found under EVA $\left(18 \mathrm{~m}^{-2}\right)$. Pisaster ochraceus is not commonly found subtidally in southern California, making its high density $\left(1.5 \mathrm{~m}^{-2}\right)$ quite remarkable. The presence of approximately 200 Pycnopodia helianthoides below EVA is also noteworthy. This camivorous, multi-armed sea star, an abundant and important component of nearshore rocky bottom ecosystems in the northwestern United States 
(Mauzey et al., 1968), is seen only rarely elsewhere in southern California, and small individuals (common under EVA) are even more unusual to find in natural situations.

Platform EVA is located approximately $10 \mathrm{~km}$ from the nearest natural hard substrate. All asteroid species under the platform, with the possible exception of Pisaster brevispinus and Pycnopodia helianthoides,
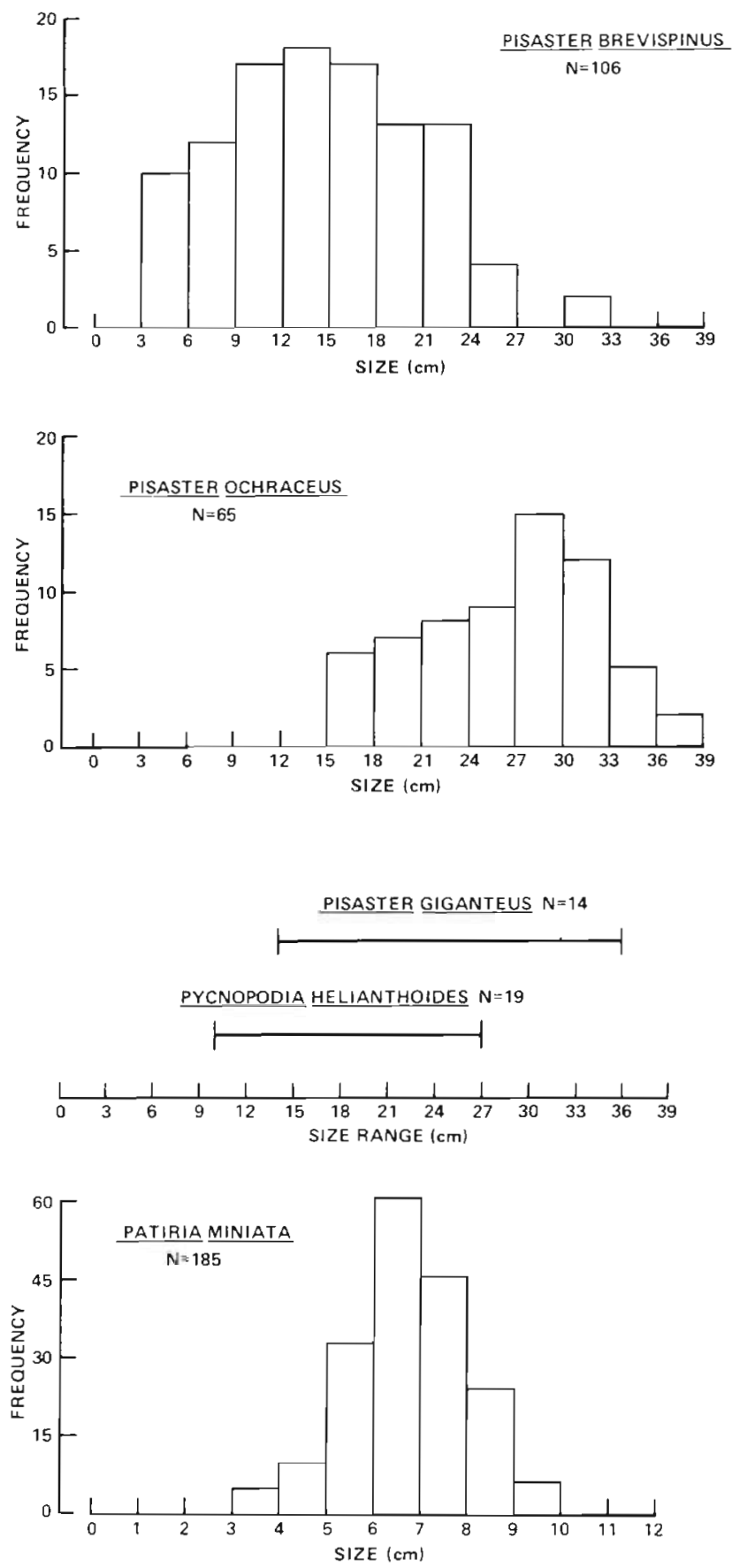

Fig. 1. Size [arm radius]-frequency distribution of asteroid species below Platform EVA. Size range only shown for the two least abundant species prefer rocky bottoms (Hopkins and Crozier, 1966), although P. brevispinus and Patiria miniata will readily cross soft substrates. Pisaster ochraceus and Pisaster giganteus occasionally traverse soft bottoms but appear to do so with reluctance. Colonization of the platform area by these last two species may have taken place by larval settlement and/or transport of adults on mats of dislodged algal material moved across the bottom by surge and currents (Fager, 1971).

Another unusual feature of EVA's sea star aggregation was the presence of individuals of each species spanning a wide range of size classes (Fig. 1). Paine (1976a) reports that Pisaster ochraceus populations in different areas of the rocky intertidal of Washington are characterized by one dominant size class and that at higher densities, the mean individual size is smaller. Under EVA, we not only observed a high density of sea stars with a wide size range within each species, but unusually large individuals of each species of asteroid were present.

Results from $0.5 \mathrm{~m}$ by $50 \mathrm{~m}$ band transects directed away from the edges of the platform (Fig. 2) indicated that the bat star Patiria miniata was the dominant asteroid on the bottom adjacent to EVA. Bat star density declined rapidly with distance from the platform edge, approaching zero at 40 to $50 \mathrm{~m}$. Unlike other asteroids associated with EVA, bat stars will consume detritus and are therefore able to feed on particulate organic matter falling from EVA's support complex. The other sea stars under EVA probably require direct access to live mussel clumps, relatively few of which fall beyond the platform perimeter.

None of the large echinoderms observed under or near the platform was found along the $1 \mathrm{~m}$ by $25 \mathrm{~m}$ comparison area. The only asteroid present was the sand star Astropecten verrilli (21 individuals in $25 \mathrm{~m}^{2}$ ), a common resident of nearshore sand bottoms in southern California.

In summary, these data on benthic echinoderm populations beneath EVA indicate that sea star densities are approximately three orders of magnitude greater than natural levels in the surrounding area, and that platform-associated species are not typical residents of the sand substrate upon which EVA was constructed.

\section{The Sand Community}

The mean grain diameter of sand samples declined from a high value of 170 microns at the edge of the shell pile below EVA to 88 microns at $20 \mathrm{~m}$ from the shell accumulation, beyond which the grain size composition remained essentially constant (Fig. 3). The samples from the shell pile edge and $5 \mathrm{~m}$ distant 


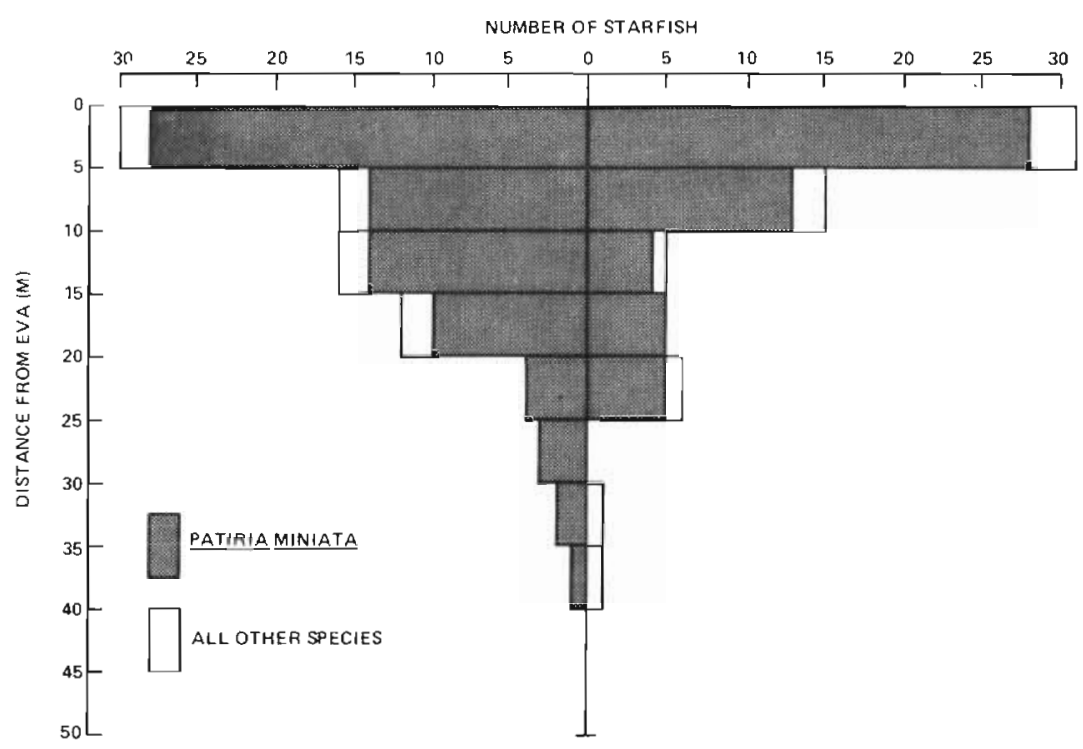

Fig. 2. Abundance of sea stars as a function of distance from EVA. Data are combined from two band transects. Horizontal bars indicate number of sea stars on either side of transect midlines
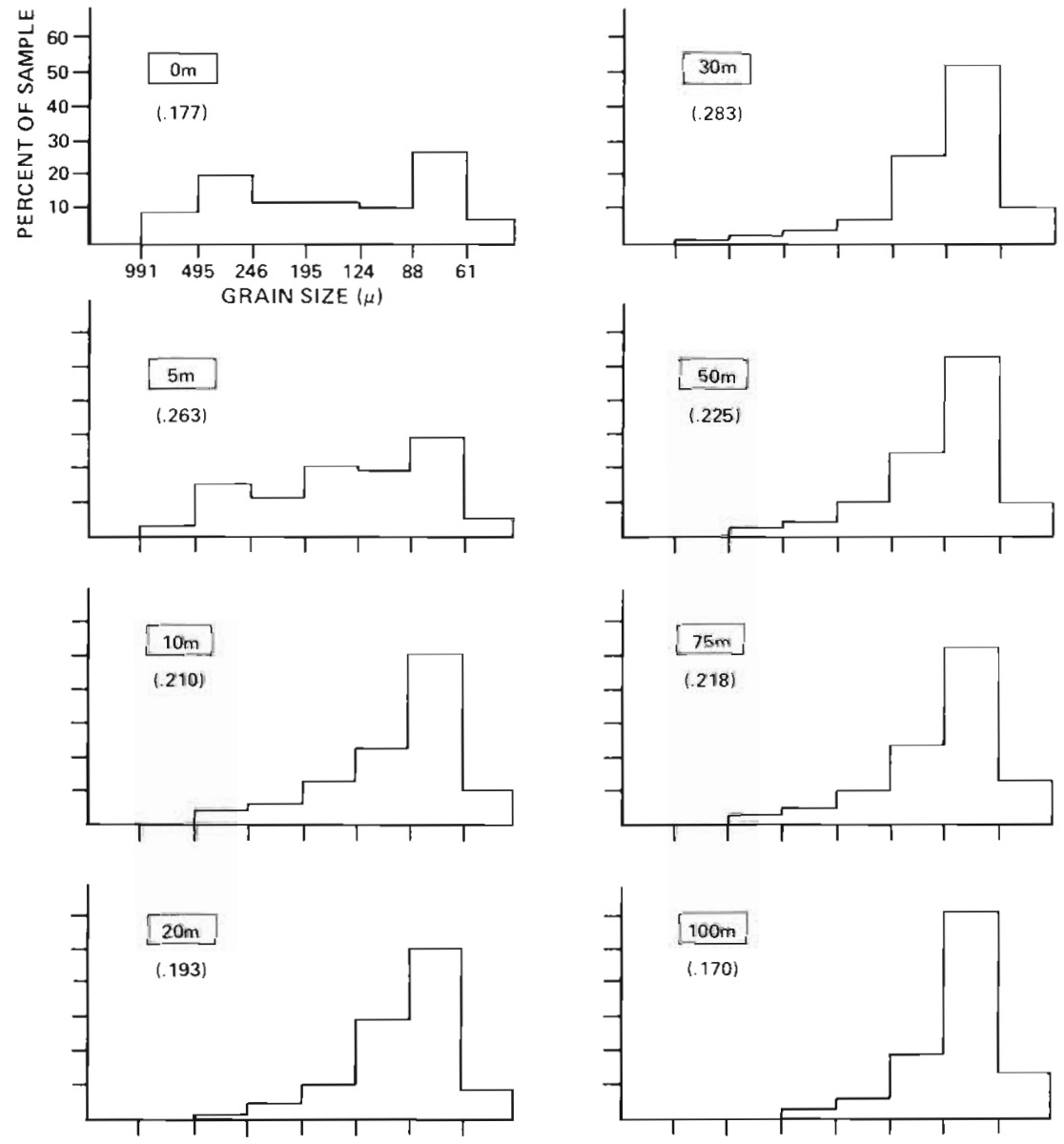

Fig. 3. Sediment grain size distribution and organic carbon content, with distance from EVA. Histograms represent the average of two replicate samples and show percentage of sample (vertical axes) in various size fractions (horizontal axes, in microns).

Percent organic carbon is given in parentheses 
showed a polymodal size frequency distribution, while those from $10 \mathrm{~m}$ and beyond were clearly unimodal. Microscopic examination showed that sediments from coarse modes of the $0 \mathrm{~m}$ and $5 \mathrm{~m}$ samples were dominated by sharply angular, non-biogenic particles, with few shell fragments or other animal products present. These data suggest that near-platform sediments consisted of natural fine sands to which significant quantities of well-drilling cutting from EVA have been added.

Estimates of sediment organic carbon composition are also shown in Figure 3. No clear relationship between carbon content and distance from EVA was apparent. The mean percent organic carbon was highest at the $30 \mathrm{~m}$ station $(0.283 \%)$, but there was considerable scatter in all samples along the transect.

Among epifaunal species which could be visually censused along the $100 \mathrm{~m}$ band transect running across the sand bottom to the east of EVA, the tube-dwelling onuphid polychaete Diopatra ornata was by far the most abundant. Its density showed a marked inverse relationship with distance from the platform (Fig. 4).

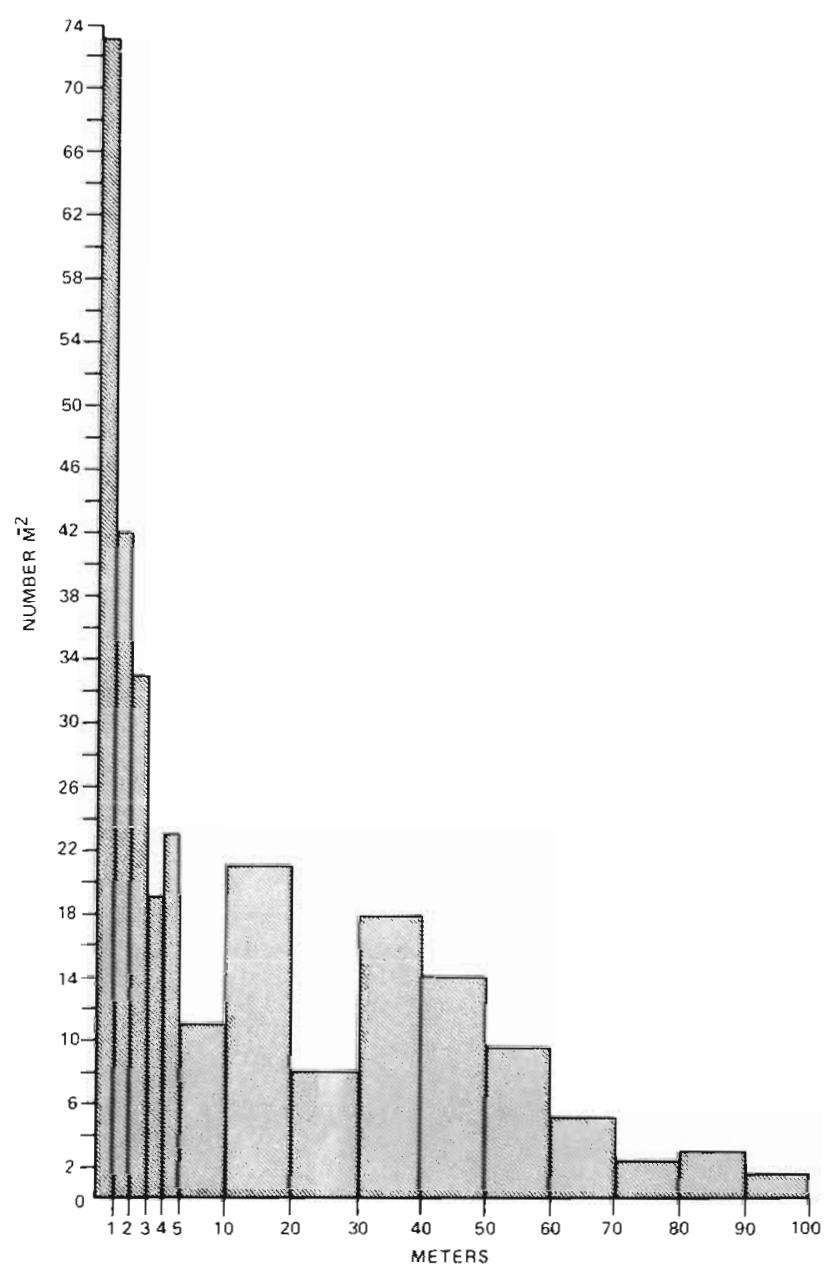

Fig. 4. Diopatra densities with distance from EVA
Densities as high as 73 individuals $\mathrm{m}^{-2}$ were recorded at the edge of the shell pile, but numbers declined rapidly with distance from EVA. Furthermore, the minimum density recorded along the transect extending away from EVA $\left(1.6 \mathrm{~m}^{-2}\right.$ in the 90 to $100 \mathrm{~m}$ interval) exceeded the mean density along the comparison transect $\left(0.5 \mathrm{~m}^{-2}\right)$. Thus, the positive influence of EVA upon population densities of $D$. ornata may extend well beyond $100 \mathrm{~m}$ from the edge of the platform.

Diopatra ornata is able to function as a deposit feeder or herbivore, depending on the availability of drift macroalgae; its larvae settle preferentially in sediments with high organic content (Emerson, 1976). We observed no distinct gradient in sediment organic content with distance from EVA. However, an alternative explanation for the enhanced density of this tube worm adjacent to EVA is possible. Near the platform, the tube caps contained many fragments of mussel shells and barnacle tests which had undoubtedly fallen from EVA's fouling community. Such biologically-generated carbonate fragments were rare in tube caps of $D$. ornata in the control area. Thus, high densities were correlated with availability of tube construction materials which fall from EVA. The absence of biogenic fragments in sediment samples near the platform may be due to active removal by the abundant worms.

In survey dives under two production platforms, HAZEL and HILDA, in the Santa Barbara Channel off southern California (depths $30.5 \mathrm{~m}$ and $33.5 \mathrm{~m}$, respectively), we observed similarly high densities of Diopatra ornata along the margins of mussel shell piles under both platforms. As with EVA, numbers declined rapidly with distance away from the shell pile edges. $D$. ornata is also often found in sandy sediments near structures such as sand dollar beds, kelp beds (Emerson, 1976) or artificial reefs (Davis, 1978) where it may display similar distributional patterns.

In contrast to the platform area, few asteroids were found in the $1 \mathrm{~m}$ by $100 \mathrm{~m}$ transect extending eastward from EVA. Eight Patiria miniata were present in the first $10 \mathrm{~m}$, four in the next 10 , but only two in the remaining $80 \mathrm{~m}$. No sand stars Astropecten verrilli were seen in the first $60 \mathrm{~m}$ of the transect, whereas one was seen in each $10 \mathrm{~m}$ interval in the remaining $40 \mathrm{~m}$. This density $\left(0.1 \mathrm{~m}^{-2}\right)$ is significantly lower than the sand star density observed in the control area $\left(0.84 \mathrm{~m}^{-2}\right)$ (Rank Sums test, $\mathrm{p}=0.001$ ). The comparison transect densities are, however, quite comparable to sand star densities on similar bottoms at the same depths elsewhere in southern California (Davis, 1978). Remnants of $A$. verrilli have been found in stomachs of two fish species abundant near artificial structures on sand bottoms in California: the embiotocid Phanerodon furcatus and the serranid Paralabrax nebulifer (Davis, 1978). A third fish, the labrid Pimelometopon 
pulchrum, is also suspected to occasionally feed on sand stars. During dives at EVA we observed groups of $P$. furcatus and $P$. nebulifer foraging on the sand bottom as far as $45 \mathrm{~m}$ from the edge of the platform. All three species of fish were abundant among the submerged legs and braces of EVA. Predation by these fishes may be responsible for the reduced densities of sand stars near the platform.

Infauna collected in the core samples included a total of 106 species, with numerical dominance by polychaetous annelids (47 species). The remainder were primarily peracarid crustaceans and bivalve and gastropod molluscs. Most of the infaunal species found in the core samples were deposit feeders, but other groups (suspension feeders, scavengers, carnivores) were also represented. A full description of the complex abundance patterns of these species would be lengthy and is, therefore, not included here. Using selected polychaetes as an example, summary data are presented which illustrate the prominent patterns displayed by species in all taxa (Table 2). Three types of distribution are evident from these data: (1) an apparent positive response to the presence of platform EVA, (2) an apparent negative response to platform presence, and (3) no discernible response. Among polychaete species found at all eight sampling stations, the seven most abundant were tested for correlation of abundance with distance from EVA (Kendall's Tau). Three species exhibited a significant $(p \leqslant 0.01)$ negative correlation, while one species showed a significant positive correlation.

Positive and negative responses were not confined to the polychaetes. For example, the pelecypod mollusc Tellina modesta is rare near EVA, but showed a significant increase with distance (Tau $=-0.49$, $\mathrm{p}<0.01$ ). An unidentified brittle star (family Amphiuridae, all individuals too small for generic identification) was the most abundant of all the infauna at the edge of the shell pile (mean density $3100 \mathrm{~m}^{-2}$ ), but its numbers declined sharply along the transect $\left(400 \mathrm{~m}^{-2}\right.$ at $\left.100 \mathrm{~m}\right)(\mathrm{Tau}=+0.511, \mathrm{p}<0.01)$. It is likely that at least some of the positive and nega-

Table 2. Presence $(+)$ of selected polychaete species in benthic core samples as a function of distance from Platform EVA

\begin{tabular}{|c|c|c|c|c|c|c|c|c|}
\hline \multirow[t]{2}{*}{ Species } & \multicolumn{8}{|c|}{ Distance (m) } \\
\hline & 0 & 5 & 10 & 20 & 30 & 50 & 75 & 100 \\
\hline Capitita ambiseta Hartman, 1947 & + & & & & & & & \\
\hline Pherusa neopapillata Hartman, 1961 & + & + & & & & & & \\
\hline Eteone californica Hartman, 1936 & + & + & + & & & & & \\
\hline Eteone dilatae Hartman, 1936 & + & + & + & + & & & & \\
\hline Armandia bioculata Hartman, 1938 & + & + & + & + & & & & \\
\hline Dorvillea articulata (Hartman, 1938) & + & + & + & + & + & & & \\
\hline Asychis disparidentata (Moore, 1904) & + & + & + & + & + & & & \\
\hline Ampharete labrops Hartman, 1961 & + & + & + & + & + & & & \\
\hline Amaeana occidentalis (Hartman, 1944) & + & + & + & + & + & & & \\
\hline Anaitides spp. & + & + & + & + & + & + & + & \\
\hline Goniada brunnea Treadwell, 1906 & + & + & + & + & + & + & + & \\
\hline Diopatra ornata Moore, 1911 & + & + & + & + & + & + & + & + \\
\hline Mediomastus spp. & + & + & + & + & + & + & + & + \\
\hline Nereis spp. & + & + & + & + & + & + & + & + \\
\hline Chaetozone setosa Malmgren, 1867 & + & + & + & + & + & + & + & + \\
\hline Lumbrineris sp. & + & + & + & + & + & + & + & + \\
\hline Spiophanes bombyx (Claparéde, 1870) & + & + & + & + & + & + & + & + \\
\hline Haploscoloplos elongatus (Johnson, 1901) & + & + & + & + & + & + & + & + \\
\hline Chone gracilis Moore, 1906 & + & + & + & + & + & + & + & + \\
\hline Harmothoe sp. & + & + & + & + & + & + & + & + \\
\hline Aricidea neosuecica (Hartman, 1965) & + & + & + & + & + & + & + & + \\
\hline Gyptis arenicola glabra (Hartman, 1961) & + & + & + & + & + & + & + & + \\
\hline Glycera sp. & + & + & + & + & + & + & + & + \\
\hline Nephtys cornuta franciscana (Clark, 1955) & + & + & + & + & + & + & + & + \\
\hline Paraprionospio pinnata (Ehlers, 1901) & & + & + & + & + & + & + & + \\
\hline Nothria elegans (Johnson, 1901) & & + & + & + & + & + & + & + \\
\hline Tharyx sp. & & & + & + & + & + & + & + \\
\hline Axiothella rubrocincta (Johnson, 1901) & & & & + & + & + & + & + \\
\hline Laonice sp. & & & & & + & + & + & + \\
\hline Glycinde sp. & & & & & + & + & + & + \\
\hline Thalenessa spinosa (Hartman, 1939) & & & & & & + & + & + \\
\hline Pista sp. & & & & & & + & + & + \\
\hline Typosyllis armilaris (Müller, 1771 ) & & & & & & & + & + \\
\hline
\end{tabular}


tive responses to platform presence relate to higherorder competitive, predatory, and larval recruitment interactions whose results are sensitive to the proximity of a large structure such as platform EVA. Controlled field experiments would be required to determine the relationship between such physical and biological factors and observed distributional patterns.

\section{A Trophic Model}

The benthic animal communities associated with platform EVA have organizational features which facilitate modelling of quantitative trophic relationships. The primary consumer biomass is dominated by two species of mussels which remain fixed in time and space. Virtually all of the export of primary consumer biomass occurs in a known direction (downward to the bottom) where it is consumed by primary carnivores with few available alternative sources of nutrition. Beyond metabolic loss, there is probably little export of carnivore biomass away from the platform area. Thus the oil platform associates at EVA form a trophic system which is relatively simple, physically localized, and has few pathways for energy loss and material transport.

The high densities of sea stars under EVA are evidence of an impressive primary consumer productivity l)y the attached mussels. We have estimated fouling community productivity in two ways. First, we have determined that the five most abundant asteroid species on the bottom form $16,725 \mathrm{~kg}$ of wet live biomass. Assuming a mean sea star feeding rate of $1 \%$ of body weight day ${ }^{-1}$ (Feder, 1970), the sea star population will require about $167 \mathrm{~kg}$ of wet (tissue) Mytilus spp. biomass day ${ }^{-1}$. If mussel fouling biomass is assumed to be at steady state (as it has appeared visually on repeat visits to EVA), $167 \mathrm{~kg}$ wet biomass day ${ }^{-1}$ becomes the estimate of primary consumer productivity. The second method involves an extrapolation based upon the volume of the shell pile beneath the platform. The mean depth of the shell pile is $3 \mathrm{~m}$, tapering to zero at a distance of 16 to $21 \mathrm{~m}$ from the platform perimeter. From these data the volume of the pile is estimated at $3115 \mathrm{~m}^{3}$. If steady state conditions have existed since installation, the mean accumulation rate has been $283 \mathrm{~m}^{3}$ year ${ }^{-1}$, or $0.78 \mathrm{~m}^{3}$ day $^{-1}$. This daily rate is equivalent to $12 \mathrm{~kg}$ Mytilus spp. dry weight, excluding shells (Harger and Landenberger, 1971 ), or $70 \mathrm{~kg}$ wet weight (Menge, 1972). This last estimate involves two assumptions: (1) One $\mathrm{m}^{3}$ of live mussels produces one $\mathrm{m}^{3}$ of shell debris, and (2) no time was required following the construction of EVA for the fallout rate to stabilize at its average value. These assumptions are overly conservative, however, since dead shells compact, occupying less volume than live animals, and significant mussel fallout probably did not begin for at least a year after EVA's emplacement. If a compaction of $20 \%$ is assumed, and a delay of one year is allowed before commencement of significant fallout, the resulting productivity estimate increases to $96.8 \mathrm{~kg}$ wet mussel biomass day ${ }^{-1}$, which is within a factor of two of the productivity estimate by the first method. The volume of live mussels equivalent to $96.8 \mathrm{~kg}$ and $167 \mathrm{~kg}$ of wet tissue biomass is caiculated to be $1.07 \mathrm{~m}^{3}$ and $1.85 \mathrm{~m}^{3}$, respectively. The volume of live mussels on EVA is approximately $617 \mathrm{~m}^{3}$. The annual loss of mussels via fallout to the bottom is thus estimated by the two computation methods at $63 \%$ and $109 \%$ of the standing crop on the platform. To maintain steady state, then, the attached mussel population must replace itself every 11 to 18 months.

While recognizing the simplifying assumptions inherent in this model, we believe the energy budget derived for platform EVA represents a good first approximation of rates of turnover and consumption in this system. Certain key interactions may be of paramount importance in determining these rates. For example, the repulsion of Pisaster spp. by Corynactis californica, a simple behavioral interaction which requires little energy transfer, probably prevents significant reduction of the mussel populations by predation. If the anemones were not present, the major pathway of energy transfer would probably shift from consumption of fallen mussels on the bottom to direct predation by sea stars on the platform support structure. This hypothesis could be readily tested by controlled field experiments involving manipulation of anemone densities.

We have found the offshore oil platform environment well-suited to the study of marine benthic ecosystems. These structures harbor a variety of community types, in close proximity, which appear in many cases to constitute closed, virtually self-contained systems. In the brief duration of our field work at platform EVA, we have found a number of interesting distributional patterns which seem amenable to analysis by field experiment. To the extent that the results of such programs can be applied to natural ecosystems, research on offshore platforms holds the promise of contributing to the advancement of ecological theory. In response to overwhelming economic pressures, the numbers of offshore production facilities are likely to increase dramatically, in the near future. Marine ecologists should consider oil platforms as a useful resource for the study of patterns and interactions among marine plant and animal populations. 
Acknowledgements. This research was sponsored by the International Biological Consultants Research Fund. Structural information and logistical support on EVA were graciously provided by K. Guziak and E. J. Schmidt, Union Oil Company of California.

\section{LITERATURE CITED}

Carlisle, J. G. Jr., Turner, C. H. and Ebert, E. E. (1964). Artificial habitat in the marine environment. Bull. Dep. Fish Game St. Calif., 124, 1-93.

Chan, G. (1973). Subtidal mussel beds in Baja California, with a new record size for Mytilus californianus. Veliger, 16 , $239-240$.

Davis, N. D. (1978). Studies of the southern California nearshore sand bottom community. Ph. D. thesis, University of California, San Diego

Emerson, R. R. (1976). The biology of a population of Diopatra ornata at Santa Catalina Island, California. Ph. D. thesis, University of Southern California.

Fager, E. W. (1971). Pattern in the development of a marine community. Limnol. Oceanogr, 16, 241-253.

Feder, H. M. (1970). Growth and predation by the ochre sea star, Pisaster ochraceus, in Monterey Bay, California. Ophelia, 8, 161-185.

George, R. Y and Thomas, P. J. (1975). Aspects of fouling on offshore oil platforms in Louisiana shelf in relation to environmental impact. Gulf University Res. Consort. Offshore Ecological Investigations. G.U.R.C. Contract No. $853,1-12$.

Haderlie, E. C. (1968). Marine fouling and boring organisms in Monterey harbor Veliger, 10, 327-341.

Harger, J. R. E. and Landenberger, D. E. (1971). The effects of storms as a density dependent mortality factor of sea mussels. Veliger, 14, 195-201.

Hopkins, T. S. and Crozier, G. F. (1966). Observations on the asteroid echinoderm fauna occurring in the shallow water of southern California. Bull. Sth. Calif. Acad. Sci., 65, 125-145.

Inman, D. L. (1952). Measures for describing the size distribution of sediments. J. sedim. Petrol., 22, 125-145.

Landenberger, D. C. (1967). A study of predation and predatory behavior in the starfish, Pisaster. Ph. D thesis, University of California, Santa Barbara.
Landenberger, D. C. (1968). Studies on selective feeding in the Pacific starfish Pisaster in southern California. Ecology, 49, 1062-1075.

Mauzey, K. P., Birkeland, C. and Dayton, P. K. (1968). Feeding behavior of asteroids and escape response of their prey in the Puget Sound region. Ecology, 49, 603-619.

Mearns, A. J. and Moore, M. M. (Eds.) (1976). Biological Study of Oil Platforms Hilda and Hazel, Santa Barbara Channel, California, Final Report. Institute of Marine Resources, Scripps Institution of Oceanography, La Jolla, California

Menge, B. A. (1972). Foraging strategy of a starfish in relation to actual prey availability and environmental predictability. Ecol. Monogs., 42, 25-50.

Paine, R. T (1966). Food web complexity and species diversity. Am. Nat., 100,65-75.

Paine, R. T (1974). Intertidal community structure: experimental studies of the relationship between a dominant competitor and its principal predator Oecologia, 15, 93-120.

Paine, R. T (1976a). Size-limited predation: an observational and experimental approach with the Mytilus-Pisaster interaction. Ecology, 57, 858-873.

Paine, R. T. (1976b). Biological observations on a subtidal Mytilus californianus bed. Veliger, 19, 125-130.

Rosenthal, R., Clarke, W and Dayton, P. (1974). Ecology and natural history of a stand of giant kelp, Macrocystic pyritera, off Del Mar, California. Fish. Bull. U. S., 72, 670-683.

Shinn, E. A. (1974). Oi] structures as artificial reefs. In L. Colinga and R. Stone (Eds), Proceedings of an International Conference on Artificial Reefs. Texas A and M. University (SA - 74-103). pp. 91-96.

Sonnier, F., Teerling, J. and Hoese, H. D. (1976). Observations on the offshore reef and platform fish fauna of Louisiana. Copeia, 1, 105-111.

Vance, R. R. (1978). A mutualistic interaction between a sessile marine clam and its epibionts. Ecology, 59, 679-685.

Wolfson, A. (1976). Submerged platform structure communities. In A. J. Mearns and M. M. Moore (Eds), Biological Study of Oil Platforms Hilda and Hazel, Santa Barbara Channel, California, Final Report, Institute of Marine Resources, Scripps Institution of Oceanography, La Jolla, California. pp. 38-44.

Wolfson, A and Parr, T. (1975). The marine life of offshore oil drilling platform EVA. Marine Ecological Consultants of southern California. Tech. Rep. No. 75-11

This paper was presented by Dr. N. D. Holland; it was accepted for printing on May 21, 1979. 